\title{
Organizational-technical mechanism of
}

\section{management of tourist-recreational complex in Republic of Tatarstan}

\author{
Galimova Leysan Ismagilovna \\ Kazan Federal University, \\ Kazan, Russia
}

\author{
Galimov Shamil' Shagitovich \\ Kazan Federal University, \\ Kazan, Russia
}

\author{
Gainetdinov Vladlen Il'gizovich \\ Kazan Federal University, \\ Kazan, Russia
}

\begin{abstract}
The effective development of the socio-economic system of the Russian Federation in modern conditions involves increasing the impact of using the potential of innovative spheres, among which one of the most important is the tourism industry. Currently, the state carries out active food in ensuring the development of the industry, but the mechanisms are not very effective. These circumstances dictate the necessity of rational organization of management of regional tourist-recreation complex on the basis of application of the process approach and the tone of the role and place of this sector in ensuring innovative development of the meso-level of socio-economic system. The article considers the approaches to the former and the functions of the tourist-recreation complex management system of the region by highlighting additional prerequisites that are important for the modern stage of tourism development as a specific way of life of the population. Effective public management of the tourist-recreation complex on the meso-level determines the growth of welfare of the regions, which consists of three key components, important from the point of view of the development of the region as an open socio-economic system, which is the soup of entrepreneurship of the sector, the population and public authorities. The efficiency of the regional broadcasting company is advisable to assess as the soup, the budget, economic and household components of the effectiveness. The article presents ways to increase revenues of the Republican budget by the example of the Republic of Tatarstan as a result of the introduction of measures for the interaction of budgetary, economic and household structures, by improving the system of regional management and interaction of elements of the touristrecreational complex.
\end{abstract}

Keywords - Republic of Tatarstan, regional management, tourist-recreation complex, tourism, formal and informal institutions, Kazan, Sviyazhsk.

\section{INTRODUCTION}

With its multiplicative effect, tourism as a whole is able to create conditions for the economic recovery of a number of Russian regions, increasing employment, more complete satisfaction of citizens' needs for recreation. At the same time, the development of the recreation market should become a priority direction of state policy, as this direction is a perspective branch of the economy and makes a great contribution to the formation of the national income of the country. The contribution of the tourism industry as a whole to the economy of the country is determined by the state policy, which should ensure political and economic stability; favorable regime of entry and exit from the country; environmental safety; protection of historical and cultural heritage, etc.

With the transition to market relations and the loss of state monopoly in a number of sectors of the economy, the partial absence of the vertical power led to disunion, loss of connections, discrepancy of interests of participants of various fields of activity, including in the recreational industry. The sphere of national tourism in Russia during the economic reform of the 1990s was objectively in terms of selfsufficiency and self-financing. Today, national tourism is deprived of financial support from the state, despite the creation in most regions of the Russian Federation structures designed to coordinate and develop tourism [6].

In our opinion, the problem of maintaining a sufficiently capacious market due to the demand of the mass Russian consumer is fundamentally unsolvable without the financial support of the State. The source of this support can be organized in two ways: through the budget and extrabudgetary. But in any case, such support should be understood as a state obligation, not charity. The strategic way of this approach is to create a new organizational and legal system of functioning and development of the tourist and recreational complex of the country.

One of the most difficult national economic systems is the regional complex, which unites branches of regional economy. This system includes the tourism industry. The tourism industry involves the provision of services in the form of a tourist product at infrastructure facilities, which are also objects of the regional economy and participate in the formation of a tourist product. The tourist product itself is an object of cultural, historical, natural heritage, which has a certain territory, in our case, the region. 


\section{RESULTS}

The formation, promotion and implementation of the tourism product is a complex socio-economic system, where related industries (trade, banking, insurance companies, catering, accommodation) are interested in earning income from joint activities.

Therefore, we believe that tourism is a multispheral complex, which involves the interaction of many sectors of the economy and for its successful functioning, management tools are needed to coordinate and regulate at the level of socioeconomic interaction, both at the regional, local and Federal levels.

Like other related industries, the tourism industry is involved in improving the social and economic living standards of the population of the region, provides additional jobs, it has a positive impact on the employment rate of the population and indicates an increase in income.

We can state that the tourist product is a material and cultural resource belonging to the region, but at the same time, if we consider the use of tourist products as a heritage, it becomes the object of international organizations, such as UNESCO, the International Bank. The regional programme should focus not only on increasing attractiveness at the global level, but also on expanding the material and technical base. Through the development of projects for the development of tourist and recreational zones, which in the future will develop as tourist-recreational complexes.

This can be clearly seen on the example of the Republic of Tatarstan on tourist-recreational complex "Sviyazhsk".

The above-mentioned complex belongs to the category of small historical cities, is an ecological, architectural and artistic platform, until 2007 it was an attractive tourist area, which was perceived as a Parking lot, where the objects of the middle ages are presented.

Over the past ten years, island Sviyazhsk has moved to the status of a tourist "core", which is the center of the tourist and recreational complex located on the coast of the Volga river, for the transition to the status of the complex, the following measures have been taken: the deepening of the Volga river near the island, which allowed to build piers not only for boats but also for river boat "aircraft" descending downstream to the river Volga from North-Western part of Russia, already in the Rybinsk reservoir, respectively Sviyazhsk became a part of cruise tourist product "Kizhi -....- Sviyazhsk-SamaraAstrakhan'". To attract private investment, were made two service reception areas for tourists, one area involves the arrival through the use of road transport. The second zone, as mentioned above, on the route of water transport. On the territory of the tourist-recreational complex there are shopping malls, where they actively sell souvenirs, handicrafts, catering facilities, a children's town, built on the grounds of Pushkin's fairy tales, interactive handicraft workshops, which are used for events (Sviyazhsk pancake week, Sviyazhsk fish soup, Theatre season in Sviyazhsk), there are also historical reconstruction events. For excursions there is a circular hiking trail with observation platforms, as well as areas for recreation and waiting, well-developed tourist information service.
All this together influenced the scantiness of the historical center, along with the development it lost a sense of solitude with history and the feeling that you are far from civilization. Of course, the development of this territory as a tourist and recreational complex had a positive impact on the dynamics of tourist flows, which affected the regional budget, as well as in connection with the recognition and popularity of the complex, money was raised for the preservation and restoration of cultural heritage, since the UNESCO world heritage site appeared on the territory of the complex in 2017.

Using the experience of the Republic of Tatarstan, we conclude that one of the urgent tasks of the development of the regional management system of the tourist-recreational complex is the formation of an effective communication system, which includes an info-communicative network that unites travel companies, hotel industry, transport infrastructure, due to the use of a single communication channel. Today, IT-representatives of the region are working to increase the speed of information transfer within the touristrecreational complex, which will have a qualitative impact on the timing of application processing and the ability to offer the tourist an alternative to the services, according to the social status and (or) the purpose of the trip.

Introducing an electronic info-communicative network within the regional tourist and recreational complex, we will provide high-speed and direct contact of interested parties in the implementation of information interaction of the elements of the complex under consideration. This involves the use of direct contact of business entities of the tourism and recreation industry, moving this network into the field of electronic records management. Such organization of interaction of the organizations of the industry of tourism and rest in the region will allow to increase quality and speed of their communication interaction and, as a result, to increase its attractiveness for clients.

The basis of effective interaction of tourist structures is formal and informal institutions that provide interaction between business structures and households at the regional level in the development of the tourist and recreational complex [4].

Table 1 presents the formal and informal institutions that support the interaction of the above-mentioned structures. 

DEVELOPMENT OF TRC OF THE REGION [2]

\begin{tabular}{|c|c|c|c|}
\hline $\begin{array}{l}\text { pn } \\
\text { sc }\end{array}$ & $\begin{array}{l}\text { Initiator of formation and } \\
\text { development of the Institute }\end{array}$ & Formal institutions formed by the initiator & Informal institutions formed by the initiator \\
\hline 1 & Farms & $\begin{array}{l}\text { - introduction of proposals on normative regulation } \\
\text { of the educational sector of the SEC } \\
\text { - making proposals for the normative regulation of } \\
\text { the availability of TRC services }\end{array}$ & $\begin{array}{l}\text { - formation of the need for the services of the SEC region } \\
\text { - formation of the image of the SEC region } \\
\text { - formation of the professional environment of the region } \\
\text { - staffing the development of tourist and recreational } \\
\text { clusters on the basis of labor contracts }\end{array}$ \\
\hline 2 & Business structure & $\begin{array}{l}\text { - making proposals for regulatory and legislative } \\
\text { regulation of entrepreneurial activity in the SEC } \\
\text { - making proposals on the formation and regulation } \\
\text { of cluster formations in the tourism and recreation } \\
\text { industry }\end{array}$ & $\begin{array}{l}\text { - formation of the proposal within the SEC } \\
\text { - formation of the image of the SEC region } \\
\text { - formation of norms of professional behavior in the SEC } \\
\text { region } \\
\text { - forming of the order for training of specialists for work } \\
\text { in TRK } \\
\text { - formation of the traditions of development of TRC of } \\
\text { the region } \\
\text { - business support for the development of tourist and } \\
\text { recreational clusters }\end{array}$ \\
\hline 3 & Public authority & $\begin{array}{l}\text { - formation of the regulatory framework for the } \\
\text { regulation of the SEC region } \\
\text { - formation of mechanisms of administration of the } \\
\text { SEC region } \\
\text { - development of information and consulting support } \\
\text { for the development of the SEC } \\
\text { - formation of financial policy regulating the } \\
\text { development of the SEC } \\
\text { - formation of the regulatory framework for the } \\
\text { creation and development of tourist and recreational } \\
\text { clusters }\end{array}$ & $\begin{array}{l}\text { - formation of the image of the SEC region } \\
\text { - making proposals on the formation of ethical norms of } \\
\text { behavior of participants of the SEC } \\
\text { - administrative and Advisory support for the } \\
\text { development of tourist and recreational clusters }\end{array}$ \\
\hline
\end{tabular}

So, the effective institutional regulation of the touristrecreational complex of the region involves the active interaction of all elements of the economy of the region, which is reflected in the target program of activities for the development of the tourism and recreation industry.

In recent years, in preparation for major sporting events, Tatarstan has had an attractive material base of tourism: new hotel complexes have been built, the existing hotel Fund of the Republic has been reconstructed by $87 \%$. One should note the importance of comprehensive development of tourism infrastructure, including associated infrastructure (transport, catering, entertainment, tourist facilities, etc.). The placement of newly constructed tourist complexes should take into account both the parameters of tourist demand by type of tourism and the nature of the tourist supply - the availability of tourist resources, conditions for staffing, in accordance with environmental requirements and economic feasibility [5].

Taking into account the nature of the tourism resources of our Republic, as well as the state of the tourism infrastructure and readiness of the tourism product, of particular interest for the development of incoming tourism in the Republic of Tatarstan may be: cultural, educational, educational, event, environmental, rural, ethnic types of tourism.

An important direction of development of the tourist and recreational complex in the region is the work on improving the quality of tourist and recreational services. The state Committee of the Republic of Tatarstan on tourism together with associations and guilds in the field of tourism accredited specialists working in the field of tourism, namely accreditation of instructors to ensure the safety of travel associated with the passage of tourist routes, guides, guides, guides (translators) in order to strengthen the unity of cultural and information space.

In order to improve the quality of tourist services, the state Committee of the Republic of Tatarstan on tourism carries out measures to increase the number of hotels in the region with categories, supports the existence of such accommodation facilities as hostels that are in demand among the young population. It implements a system of classification of beaches and takes part in the development of professional standards of service by creating the inclusion of employers' requirements in the form of professional standards in educational programs for the training of personnel for the tourism industry.

\section{CONCLUSION}

The Republic is actively creating conditions for improving the skills of tourism and hotel business on the most pressing issues of practical activities.

The proposed program had a positive impact on the revenues of the national budget, as a result of the introduction of the system of regional management of the tourism sector on the basis of the proposed tools and mechanisms it achieved the quality of interaction elements of the tourist and recreational complex. As a result, transaction costs are reduced by reducing unproductive communication operations, as well as the speed of servicing customers of the regional tourist complex, resulting in an increase in turnover in the field of tourism and recreation, while maintaining the present level of profitability of business entities in this industry, which, in turn, led to an increase in revenues of the complex as a whole. 
The result of such changes at the regional level was an increase in tax revenues in terms of corporate income tax and taxes levied in connection with the use of a simplified tax system (which uses a significant number of economic entities of the tourism industry),

All this will allow one to receive additional budget income in the amount of more than 200 million rubles. This fact confirms the economic feasibility of the proposed measures.

Thus, in order to improve the efficiency of the regional socio-economic system in terms of the development of the tourism and recreation industry, it is necessary to implement a set of measures to develop the management system of this industry at the regional level.

\section{References}

[1] L.I. Abinova, Some features of development of the tourist-recreational complex of the region, Today and tomorrow of the Russian economy, 2010, № 33, pp. 164-166.

[2] L.I. Abinova, L.B. Shabanov, Rating assessment of spatial distribution of tourist and recreational capacity of the Republic of Tatarstan, Current problems of economy and right, 2013, No. 3(27), pp. 17-21.

[3] A.I. Bashirova, L.I. Galimova, Konkurentosposobnost of the tourist enterprises in Kazan. In the collection: Youth. Tourism. Education, Materials III of a scientific and practical intramural and extramural conference for school students, teachers and students, 2017, pp. 47-50.

[4] Sh.Sh. Galimov, L.I. Galimova, Methodical aspects of formation of system of financial management at the enterprises of the tourism industry, European social science journal, 2017, No. 1, pp. 124-133.

[5] L.I. Galimova, Prerequisites and conditions of creation of a tourist product, on the basis of the available tourist and recreational capacity of the Republic of Tatarstan, The international tourism and sport materials II of the All-Russian scientific and practical conference with the international participation. under the editorship of Yu.V. Zhilkova, 2014, pp. $149-152$.

[6] V.A. Gnevko, V.E. Rokhchin, Questions of the theory and practice of regional strategic government, Spatial economy, 2006, No. 4, pp. $101-$ 115 .

[7] E.L. Pisarevsky, The public and municipal administration in the sphere of tourism: textbook, group of authors; under a general edition of, M.: Federal Tourism Agency, 2014.

[8] M.A. Zhukova, Tourism industry: management of the organization: Textbook, Moscow, Finance and statistics, 2002.

[9] U. Izard, Methods of the regional analysis, Moscow, Progress, 2006.

[10] V.I. Kruzhalin, N.S. Mironenko, N.V. Zigern-Korn, N.V. Shabalin Tourism geography, Moscow, Federal Tourism Agency, 2014.

[11] A.D. Chudnovsky, N.V. Korolev, E.A. Gavrilova, M.A. Zhukova, N.A. Zaytseva, Tourism management: textbook. Moscow, Federal Tourism Agency, 2014.

[12] A. Petrov, "General theory of relativity", Annalen der Physik, vol. 49, №. 7, pp. 769-822, 1916.

[13] B.M. Eidelman, L.R. Fakhrutdinova, S.S. Galimov, Applying of the territorial marketing tecnologies in organizations of socio-culture service and tourism, International Business Management, no. 10, Issue 23, 2016, pp. 5568-5571.

[14] D. Miller, P.H. Freisen, «Momentum and revolution in Organizational Adaptation», Academy of Management Journal, no. 23, 1980, pp. 591 614.

[15] P.A. Shtrek, Ecologization managements in sphere of touristic recreational services, $\mathrm{SPb}, 2010$.

[16] UNWTO Tourism Highlights, 2017 Edition. UNWTO http://tourlib.net/wto/WTO_highlights_2017.pdf 